Government by the Market? 
Also by Peter Self

Cities in Flood

The State and the Farmer (with H. Storing)

Administrative Theories and Politics

Econocrats and the Policy Process

Planning the Urban Region

Political Theories of Modern Government 


\section{Government by the Market?}

The Politics of Public Choice

Peter Self 


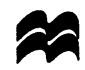

\section{(C) Peter Self 1993}

All rights reserved. No reproduction, copy or transmission of this publication may be made without written permission.

No paragraph of this publication may be reproduced, copied or transmitted save with written permission or in accordance with the provisions of the Copyright, Designs and Patents Act 1988, or under the terms of any licence permitting limited copying issued by the Copyright Licensing Agency, 90 Tottenham Court Road, London W1P 9HE.

Any person who does any unauthorised act in relation to this publication may be liable to criminal prosecution and civil claims for damages.

First published 1993 by MACMILLAN PRESS LTD

Houndmills, Basingstoke, Hampshire RG21 6XS

and London

Companies and representatives

throughout the world

ISBN 978-0-333-56973-3

DOI 10.1007/978-1-349-23111-9

ISBN 978-1-349-23111-9 (eBook)

A catalogue record for this book is available from the British Library.
$\begin{array}{lllllllll}11 & 10 & 9 & 8 & 7 & 6 & 5 & 4 & 3\end{array}$
$\begin{array}{lllllllll}04 & 03 & 02 & 01 & 00 & 99 & 98 & 97 & 96\end{array}$ 
To Hugh Stretton, fellow critic of public choice 


\section{Contents}

Preface ix

1 Economic Interpretations of Politics 1

Comparing economic and political systems 2

Basic assumptions: self-interest and rationality 4

The problem of co-operation 11

Alternative public choice 16

2 Theories of Political Behaviour 21

Voters 21

Parties 24

Interest groups: formation 27

Interest groups: influence 29

Bureaucrats 32

Demand and supply of public goods 36

How true are public choice theories? $\quad 45$

3 The Creation of a New Ideology 48

The limits of democratic choice $\quad 48$

Buchanan's constitutionalism 51

The construction of ideology 53

Public choice ideology 56

Transmission by think tank 64

4 Slimming the State 70

Leadership and ideology 70

Mobilising interests 75

The failed politics of expenditure control $\quad 80$

Winners and losers $\quad 87$

The successful politics of privatisation 93

Reversing public choice theory? 105

5 Privatising Welfare 113

The politics of welfare 113

Privatising service delivery 121

Empowering consumers 129

The public health market 135 
The scope of state welfare 141

Welfare and political change 146

6 Restructuring Government 156

Political goals and public choice theories 156

The assault on bureaucracy 159

Copying market models 167

Decentralisation, American style 176

Centralisation, British style 184

Bureaucracy and democracy 192

7 Market Ideology and Public Policy 198

Politics and ethics of markets 198

Markets in theory and practice 204

Impacts upon public policy 213

Dominance of the media 224

Assessing market influence 227

8 Public Choice and the Public Interest 232

Is there a public interest? 232

The liberty card replayed 241

Economic rights and social justice 246

Failures of the market model 253

The return to citizenship 256

9 Towards Better Government 262

Explaining government growth 262

A new political agenda 267

Reforming the market system 273

Empowering democratic government

Bibliography 282

Index of Names 296

Index of Subjects 299 


\section{Preface}

In recent decades a powerful new paradigm of the proper scope and limits of government action has become dominant in Western democracies. This paradigm holds that governments should in general do less; that they should reduce or relinquish their previous responsibilities for maintaining full employment and a comprehensive system of state welfare; that they should privatise publie services or their delivery wherever practicable; and that they should reform their own operations in accordance with market concepts of competition and efficiency. These beliefs in 'government by the market' rest upon propositions that the market system is inherently a better method for satisfying human wants and aspirations than recourse to government, and that the political process is subject to numerous imperfections and distortions. The aims of this book are to investigate the intellectual foundations of this new ideology, to examine the numerous public policies that have been (and are being) followed within its general rubric, and to evaluate these beliefs in terms of broader social values and understandings of 'the public interest'.

The intellectual basis for these new doctrines come from market theory and public choice thought. This book concentrates primarily upon the public choice element, because while market theory celebrates or defends the virtues of competitive markets (a subject taken up in Chapter 7), public choice concentrates upon the problems and limitations of the democratic political process. Thus it is able to provide a critically important collaboration to the advocacy of market theory by dealing specifically with issues of politics and political failure. Because public choice is in principle no more than an economic tool of analysis, its political uses have not been clearly recognised; and because of its economic language, public choice is a somewhat esoteric and unfamiliar subject for students of politics and the general public, at any rate outside the USA. However, public choice in simplified or popularised forms has contributed a lot to political debates 
and policies. In particular it has helped to erode the optimistic post-1945 belief in government planning and the welfare state, and to substitute the conclusion that the less governments do, the better.

Public choice theory represents the application of economic methodology to the study of politics. In principle it is an objective study not wedded to any particular political belief, but its inquiries are shaped by its strongly individualist and rationalist assumptions. These assumptions lead to a critical view of the political process owing to the many opportunities which it is said to provide for self-seeking behaviour, and an adverse view of the capacity of governments to satisfy individual wants compared with economic markets. Social choice (a related discipline) further brings in the intrinsic difficulties of making collective decisions upon a democratic basis.

The first three chapters offer a concise survey of public choice theories. My concerns have naturally been different from those of economic theorists. Public choice writers use an economic language which they do not usually relate to more conventional or traditional treatments of politics (an exception is James Buchanan, who does specifically relate his public choice theories to the history of political thought). In attempting to bridge this gap, I cannot do justice to the many sophisticated economic treatments of politics which occur in the literature, my concern being to present a readable analysis to a non-economist (although my interpretations and conclusions are also addressed to economists). The treatment has also to be selective in line with the wider purpose of the book of discussing the influence of ideas upon policies.

Thus I first take a critical look at the assumptions of public choice because they influence all that follows about the nature of politics. In Chapter $2 \mathrm{I}$ try to pull together and evaluate some public choice theories about the behaviour of principal actors in the political process. Chapter 3 shows how certain strong conclusions by public choice writers have been utilised to build up the ideology of 'government by the market'. I want to stress here that a methodology based upon the idea of rational selfinterest need not support these conclusions and can be turned instead into a strong critique of the market system. I recognise these alternative theories in the text, without having space to review them adequately, but I suggest that the highly individualist assumptions of public choice do point in a clear ideological 
direction. The public choice assumptions after all are those conventionally used to justify the market system in classical economics. Thus the main thrust of public choice writing, and still more of its political influence, have been to discredit democratic government and to extol the market system.

The next three longer chapters analyse the public policies pursued by political leaders in efforts to reduce the scope, range and costs of government and drastically to change methods of public administration and service delivery. These chapters are organised around the three themes of slimming the state, privatising welfare and restructuring government as key elements in a wide-ranging programme of political change. The examples are taken from English-speaking democracies where these political goals have been most evident, especially from Britain and the USA but also in some contexts from Australia, New Zealand and Canada. The Reagan and Thatcher years provide a laboratory for testing these policy innovations and the treatment is sometimes explicitly comparative. However, the general aim is not a comparative survey but an illustrative discussion of policies in a variety of arenas in order to demonstrate some of the goals and effects of this major shift in the relations between government and society.

This account of recent political history should have an intrinsic interest, whatever theoretical conclusions are or are not drawn. The influence of public choice thought (albeit in a popularised form) can be seen both in the general assumptions on which political leaders based their policies and also sometimes in the strategies which they pursued to disarm or overcome opposition. There is, however, a certain irony in the use or relevance of public choice thought in a policy context. The same critique of selfseeking political behaviour which supports the ideology of 'slimming the state' also suggests that the effort will be unsuccessful because of the necessary mobilisation of new interests (such as those embedded in the market system) and the costs of buying out existing interests. By the end of the 1990s it can be seen that the outcome of all these activities has been not so much to slim government itself as to alter quite drastically its economic and social responsibilities as well as its distribution of favours and sacrifices among the members of society.

The last three chapters revert to a more theoretical framework which revolves around the respective capacities of the market and political systems to satisfy individual wants and aspirations. 
Chapter 7 investigates the performance of the market system against the claims of both public choice and market theory, and goes on to discuss the powerful impact of market ideology upon public policies, using a number of illustrations. Chapter 8 shows the failures of public choice and market theories to offer any tenable concept of the 'public interest' or to satisfy basic criteria of individual rights and social justice. The defects of the political system, including its tendencies to extremism and alienation and its liability to strong ethnic or group conflicts, are also sketched. Answers to these problems are sought in the concept of responsible and active citizenship and in Chapter 9 are further pursued through the search for a new policy paradigm that could enable democratic governments to realise social values which markets cannot satisfy.

Two points should be clarified about the purposes of this book. It nowhere suggests or supposes that public policies are likely to be closely based upon academic theories or prescriptions. Politics is a highly pragmatic activity which does not consistently follow any general principles of policy. Nonetheless it is the author's belief, which has grown stronger as the book has progressed, that ideas and ideology do count a great deal in politics, even though their application is much distorted by political considerations. They provide the essential basis of assumed social realities whereby political leaders explain and justify their policies to the public, backed by a media which keeps the range of 'realistic' options within narrow limits. It is usual here to refer to Keynes' aphorism that every practical man is the slave of some defunct economist. In respect of current policies the economists in question are alive, kicking and influential, but otherwise there is truth in Keynes's statement.

Secondly, in criticising the 'self-interest' assumption of public choice, I do not mean to revert to an idealistic tradition about the state which assumes extensive public-spirited behaviour. While self-interest and altruism both exist, the former is generally the more dominant motive; but the directions and degrees of selfinterest depend very much upon the structure of opportunities within a given political and economic system, and upon the ethical norms (or their absence) which regulate behaviour in that system. In The Culture of Contentment (1992) J. K. Galbraith reaches the gloomy conclusion that highly irrational and short-sighted public policies will continue to be pursued because they suit the perceived self-interest of the affluent majority of the population 
(by which he means a majority of those voting and holding effective power, not a majority of the whole population). This view that the 'affluent' are myopic even about their own longerterm interest does not wholly square with the assumption of rational egoism, and seems to me to be too gloomy a view of the propensities and future of the human species. What seems truer is that a shift to more aggressive and short-sighted forms of selfinterest is being brought about by the retreat of democratic governments from responsible economic and social policies.

This situation raises a political issue which is now crucial (although often not recognised as such) for the life and future of democratic societies. How far must or should significant social goals be sacrificed in order to comply with the criteria of economic efficiency imposed by the workings of the international market system? Government policies have increasingly been guided by this assumed requirement, even at the cost of rising unpopularity. Political conflict and extremism have grown because of it. I am not of course reducing political events to a single cause, but suggesting that the drift from a more democratic and pluralist model of government to a less open and more authoritarian one can be partly at least explained in these terms. One lesson from this book is that governments, whether acting individually or collectively, need to recover more room for manoeuvre in the service of social goals.

I am grateful for comments on parts of the book from individual scholars. My thanks are especially due to Hugh Stretton, who read the whole draft and on particular chapters to Rudolf Klein, Harvey Feigenbaum, Phyllis Colvin, Jonathan Boston, Patrick Dunleavy, John Nethercote, Carol Weiss, Maurice Kelly, Bob Goodin, Jan Lamboy, Campbell Sharman and Peter Williams. I am also grateful for some constructive suggestions on public choice issues from my publisher's reviewers, Keith Dowding and Ian Holliday. None of these individuals have any responsibility for the use made of their advice. I have also benefited from seminar discussions on parts of the book at the Australian National University and several other Universities.

The Research School of Social Sciences in the Australian National University provided me with a supportive and friendly base for research and writing over two years as a Visiting Fellow in the urban research and politics programmes. My special thanks go to Penny Hanley in urban research for help with the bibliography and to Christine Treadwell in politics who word- 
xiv Preface

processed successive drafts with accuracy, speed and patience. My publisher, Steven Kennedy, actively helped with advice and encouragement over the design of the book. My wife Sandra did her best to keep me to a timetable and tolerated my absorption in the book with much kindness.

Canberra

Peter Self 